\title{
BUNUH DIRI DALAM PERSPEKTIF SOSIOLOGI
}

\author{
Alfan Biroli \\ Program Studi Sosiologi, FISIB, Universitas Trunojoyo Madura \\ alfanbiroli@gmail.com
}

\begin{abstract}
Suicide is an event in society that is often inevitable. Suicide is a deliberate end to life. Social symptoms in society greatly affect someone in committing suicide. Referring to Durkheim, there are at least four types of suicide, namely egoistic suicide, suicide altruism, anomie suicide, and fatalistic suicide. Egoistic suicide is a suicide that occurs because social integration is too weak. Suicide altruism is a suicide that occurs because social integration is too strong. Anomie suicide is a suicide that occurs because of the blurring of values and norms in society. Fatalistic suicide is a suicide that occurs because the values and norms that apply in society are too excessive. Suicidal acts that occur in the community can be mapped through the fact that social integration is getting stronger or weaker. In addition, suicide can also be mapped based on the fact that the values and norms are getting weaker or stronger.
\end{abstract}

Keywords: suicide, social integration, values and norms

\begin{abstract}
Abstrak
Bunuh diri merupakan kejadian dalam masyarakat yang seringkali tak terelakkan. Bunuh diri adalah peristiwa mengakhiri hidup secara sengaja. Gejala-gejala sosial dalam masyarakat sangat mempengaruhi seseorang dalam melakukan tindakan bunuh diri. Merujuk Durkheim, setidaknya ada empat tipe tindakan bunuh diri, yaitu egoistic suicide, altruism suicide, anomie suicide, dan fatalistic suicide. Egoistic suicide adalah tindakan bunuh diri yang terjadi karena integrasi sosial yang terlalu lemah. Altruism suicide adalah tindakan bunuh diri yang terjadi karena integrasi sosial yang terlalu kuat. Anomie suicide adalah tindakan bunuh diri yang terjadi karena kaburnya nilai dan norma dalam masyarakat. Fatalistic suicide adalah tindakan bunuh diri yang terjadi karena nilai dan norma yang berlaku dalam masyarakat terlampau berlebihan. Tindakan bunuh diri yang terjadi dalam masyarakat dapat dipetakan melalui fakta integrasi sosial yang semakin kuat atau yang semakin lemah. Selain itu tindakan bunuh diri juga dapat dipetakan berdasarkan fakta tatanan nilai dan norma yang semakin lemah atau semakin kuat.
\end{abstract}

Kata Kunci: bunuh diri, integrasi sosial, nilai dan norma 


\section{PENDAHULUAN}

Manusia adalah makhluk sosial, manusia tidak dapat hidup sendiri tanpa adanya bantuan dari orang lain. Manusia selalu membutuhkan kehadiran orang lain. Setiap tindakan yang dilakukan selalu berhubungan dengan orang-orang disekitar. Jika kehidupan manusia dalam sikap individu hanya mampu bertahan temporer, tidak demikian dengan sikap sosial yang akan terbangun secara lama dengan individu-individu yang beragam dalam lingkungan sosial. Segala aktivitas manusia dalam dunia sosial berhubungan dengan fakta sosial. Salah satu fakta sosial diantaranya adalah fenomena bunuh diri.

Kenyataan dalam masyarakat sudah tertampakkan bahwa kejadian bunuh diri sudah berlangsung selama puluhan tahun masa silam, bahkan sampai saat ini masih terjadi. Berbagai asumsi akan memunculkan pandangan dari masyarakat terkait adanya tindakan bunuh diri yang dilakukan oleh berbagai orang. Dengan melakukan aksi bunuh diri besar kemungkinan akan menyebabkan sebuah kematian. Kehidupan manusia memang mengalami pentahapan, bermula dari lahir tumbuh berkembang dan pada akhirnya akan mengalami kematian. Akan tetapi kematian yang terjadi dari manusia mengalami berbagai kewajaran atau bahkan diluar kenalaran. Menurut Widodo (2011: 152), kematian berdampak pada persepsi individu yang berbeda. Sebagian memandang kematian dianggap sebagai peristiwa yang sangat penting dan menakutkan, individu lain memandang kematian sebagai proses alami belaka. Perbedaan persepsi ini mengakibatkan sikap dan perilaku yang berbeda setiap individu dalam menghadapi kematian.
Kematian yang disebabkan oleh bunuh diri cenderung meningkat di seluruh dunia. Data yang ditemukan di Indonesia menyatakan bahwa bunuh diri menjadi penyebab utama kedua kematian pada usia produktif 15-29 tahun, dan rata-rata kematian karena bunuh diri di Indonesia adalah satu orang pada setiap satu jam (Kompas, 8 September 2016) dalam (Valentina dan Helmi, 2016: 123). Walaupun pada kenyataannya individu yang melakukan bunuh diri tak selamanya berada pada usia produktif, anak kecil atau orang dewasa bahkan orang tua juga bisa mengalami tindakan bunuh diri.

Kematian yang disebabkan dengan cara bunuh diri adalah sebuah tindakan yang dilakukan oleh seseorang atau kelompok. Tindakan dalam bunuh diri tidak selamanya berujung kematian, ada beberapa kejadian yang akhirnya menyelamatkannya. Walaupun pada kebanyakan kasus, tindakan dalam bunuh diri tersebut berakir pada hilangnya nyawa seseorang. Motif yang melatarbelakangi sesorang melakukan bunuh diri tentunya didasarkan pada proses sosial yang dihadapinya. Apakah selama hidupnya bisa berbaur dan bersosialisasi dengan baik di masyarakat atau justru sebaliknya. Setiap individu mempunyai pola pikir yang berbeda, ideologi yang dijalankan sesuai dengan hakikat keyakinan yang dimilikinya. Interaksi sosial dalam lingkungan sosial juga akan mempengaruhi seseorang dalam mengambil sikap yang dilakukan. Kejadian bunuh diri didasarkan atas beberapa perilaku yang mencerminkan bagaimana seseorang dalam hidupnya mengalami tekanan atau tidak. Aturanaturan yang ada dalam kehidupannya 
juga sangat berpengaruh baginya. Selain itu tekanan psikologis maupun sosiologis juga sangat besar pada perilaku seseorang dalam melakukan aksi bunuh diri.

Bunuh diri bagi masyarakat Indonesia masih menjadi sesuatu yang tidak layak atau jauh dari harapan masyarakat pada umumnya. Akan tetapi bunuh diri tersebut dilakukan oleh para pelaku yang mempunyai kepentingan tersendiri baginya atau bahkan untuk kelompok tertentu. Melihat realitas yang terjadi, bunuh diri merupakan sebuah fakta dalam masyarakat yang mana bunuh diri adalah gambaran dari para pelaku yang sengaja untuk mengakhiri hidupnya. Dalam pandangan Emile Durkheim, bunuh diri dapat dikaji secara sosiologis dengan pendekatan egoistic suicide, altruism suicide, anomie suicide, dan fatalistic suicide.

\section{PEMBAHASAN}

\section{BUNUH DIRI DALAM FAKTA SOSIAL}

Untuk memisahkan sosiologi dari psikologi, Durkheim dengan tegas membedakan antara fakta sosial dengan fakta psikologi. Fakta psikologi adalah fenomena yang dibawa oleh manusia sejak lahir (inherited). Dengan demikian bukan merupakan hasil pergaulan hidup masyarakat. Fakta sosial tidak dapat diterangkan dengan fakta psikologi. Ia hanya dapat diterangkan dengan fakta sosial pula (Ritzer, 2011: 16). Fakta sosial jelas berbeda dengan fakta psikologi. Fakta sosial sangat berhubungan dalam kehidupan manusia. Segala pergaulan hidup akan bersinggungan dengan faktafakta yang ada di lingkungan sosial atau masyarakat. Menurut Emile Durkheim (dalam Usman, 2012: 40), sosiologi adalah ilmu yang mempelajari fakta sosial.

Fakta sosial adalah bersifat eksternal terhadap individu. Fakta sosial bisa berupa cara bertindak, berpikir, dan berperasaan yang memperlihatkan ciriciri tertentu yang berada di luar kesadaran individu. Fakta sosial mempunyai kekuatan memaksa individu. Fakta sosial juga bersifat umum, dalam arti tersebar merata, menjadi milik kolektif dan bukan sekadar hasil dari penjumlahan beberapa fakta individu.

Perhatian Durkheim yang utama bukan dalam bunuh diri sebagai suatu tindakan individu melainkan dalam turun-naiknya angka bunuh diri itu. Angka bunuh diri dilihat sebagai fakta sosial dan bukan fakta individu, dan yang diharapkan dari analisa itu adalah bahwa bunuh diri dipengaruhi oleh fakta sosial lainnya seperti tingkat atau tipe integrasi sosial (Johnson, 1986: 192). Bunuh diri yang yang dilihat melalui angka pada turun-naiknya, merupakan sebuah frekuensi fakta sosial yang ada di masyarakat. Bahwa tindakan bunuh diri tersebut dilakukan di berbagai tempat sehingga berlaku secara umum. Segala tindakan dalam bunuh diri sangat dipengaruhi oleh kesadaran diluar dirinya, artinya gejala-gejala sosial yang hadir akan turut membentuk dari apa yang dijumpainya. Selain itu ketika adanya integrasi atau nilai dan norma maka akan memaksa individu untuk berada dalam lingkungan kelompok tersebut.

Bunuh diri adalah tindakan yang dapat menyebabkan kematian, disengaja, dilakukan oleh dirinya sendiri dan pelaku menganggap tindakannya sebagai jalan yang terbaik untuk menyelesaikan masalahnya (Gamayanti, 2014: 208). 
Bunuh diri merupakan tindakan yang dilakukan oleh seseorang atau kelompok tertentu untuk mengakhiri hidupnya. Tidak semua masyarakat dapat menerima dengan tindakan bunuh diri, meskipun dapat kita jumpai dimana saja dan kapan saja. Fenomena yang terjadi seseorang dapat melakukan bunuh diri karena adanya ikatan sosial atau norma yang sesuai atau tidak sesuai baginya dalam hubungan sosial di masyarakat.

Hampir di berbagai belahan dunia pernah terjadi fenomena bunuh diri baik yang dilakukan secara sendiri atau pun massal. Perilaku tersebut dimaknai sebagai perilaku yang ditandai oleh adanya gejala-gejala sosial yang tidak sesuai dengan pandangan dari hidupnya, sehingga melakukan aksi bunuh diri. Menurut Durkheim (1968) (dalam Sunarto, 2004: 12), angka bunuh diri dalam tiap masyarakat yang dari tahun ke tahun cenderung relatif konstan merupakan suatu fakta sosial. Angka bunuh diri disebabkan kekuatan yang berada di luar individu.

Perubahan-perubahan dalam tingkat integrasi dalam suatu masyarakat secara empiris dinyatakan dalam pelbagai cara. Satu manifestasi utama yang dianalisa Durkheim secara intensif adalah perubahan dalam angka bunuh diri. Misalnya, apabila solidaritas organik menurun dan tingkat anomi dalam masyarakat naik, angka bunuh diri cenderung naik (Johnson, 1986: 192). Solidaritas merupakan ikatan sosial yang terbentuk dalam masyarakat dimana mempunyai jiwa kesadaran kolektif kuat atau lemah. Semakin kuat tingkat kesadaran kolektif maka integrasi sosial semakin tinggi. Akan tetapijika kesadaran kolektif lemah, maka integrasi sosial semakin turun. Menurut Edi dan Biroli (2017, 193), integrasi sosial merupakan suatu kesatuan yang ada di masyarakat, dimana masyarakat mempunyai harapan dan dambaan agar tercipta situasi keteraturan sosial. Dengan demikian, jika integrasi sosial yang berjalan dalam masyarakat berjalan secara seimbang maka akan tercipta keharmonisan. Akan tetapi integrasi sosial yang sangat kuat atau lemah menjadi penyebab tersendiri bagi seseorang untuk melakukan tindakan bunuh diri.

Keadaan anomi juga sangat mempengaruhi terhadap tindakan bunuh diri, masyarakat menjadi bingung dan kacau. Struktur sosial yang ada tidak bisa memberikan peredaman dalam sebuah ketegangan masyarakat. Disamping itu keadaan fatalistic juga sangat mempengaruhi dalam tindakan seseorang melakukan bunuh diri. Bunuh diri terjadi karena adanya gejala-gejala sosial di masyarakat. Barang siapa tidak bisa mengikuti terhadap arus sosial maka akan terkungkung dan menjadi pribadi yang lemah. Manusia selayaknya hidup dalam keadaan sosial yang tidak terlalu kuat atau lemah dalam integrasi sosial, begitu juga dengan nilai-nilai dan norma yang berjalan dengan sewajarnya sesuai batas-batas individu dalam masyarakat.

\section{TIPE BUNUH DIRI DALAM PENDEKATAN SOSIOLOGI}

Dalam karya Durkheim yang popular Le Suicide (1897) (dalam Upe, 2010: 99), dikemukakan dengan jelas hubungan antara integrasi sosial terhadap kecenderungan untuk melakukan bunuh diri (suicide). Durkheim melihat 
bunuh diri sebagai tindakan individu dilatarbelakangi oleh faktor-faktor sosial. Durkheim menolak adanya serangkaian anggapan bahwa bunuh diri disebabkan oleh penyakit kejiwaan, imitasi atau peniruan, iklim, alkoholisme, kemiskinan, dan juga adanya pengaruh rastertentu yang memiliki kecenderungan melakukan bunuh diri.

Faktor sosial sangat mempengaruhi sekali mengapa seseorang melakukan tindakan bunuh diri. Gejala-gejala sosial sangat berpengaruh dalam diri individu ketika mempunyai hubungan sosial dalam masyarakat. Segala bentuk integrasi sosial yang kurang atau berlebihan akan mempengaruhi terhadap tindakan yang dilakukan oleh manusia. Selain itu adanya aturan yang tercipta, baik yang sangat kuat atau yang melemah juga mempunyai dampak tersendiri bagi masyarakat. Durkheim merumuskan empat tipe bunuh diri (dalam Upe, 2010: 99), yaitu: Egoistic suicide, yaitu suatu tindakan bunuh diri karena merasa kepentingan individu lebih tinggi daripada kepentingan kesatuan sosialnya. Altruism suicide, yaitu dengan adanya perasaan integrasi antar sesama individu yang satu dengan yang lainnya, maka menciptakan masyarakat yang memiliki integrasi yang kuat. Anomie suicide, yaitu lebih terfokus pada keadaan moral dimana individu yang bersangkutan kehilangan cita-cita, tujuan, dan norma dalam hidupnya. Fatalistic suicide, yaitu terjadi ketika nilai dan norma yang berlaku di masyarakat meningkat dan terasa berlebihan.

Bunuh diri yang dilakukan oleh seseorang atau kelompok tidak mengenal jenis kelamin, usia, asal-usul daerah, dan latar belakang keluarga. Tindakan bunuh diri yang dilakukan dapat dijumpai pada laki-laki atau perempuan, tidak mengenal usia baik kecil atau yang sudah dewasa. Selain itu daerah dimana ia tinggal juga bisa berasal dari daerah mana saja. Sedangkan orang yang mempunyai latar belakang status sosial miskin atau kaya juga dapat dijumpai bahwasannya seseorang tersebut dapat melakukan aksi bunuh diri. Hal tersebut menggambarkan bahwa yang sangat menentukan pada tingkatan bunuh diri adalah integrasi sosial dan norma yang berlaku dalam masyarakat. Berikut merupakan analisis sosial dalam mengidentifikasi terhadap tipe-tipe bunuh diri, diantaranya yaitu:

\section{a) Egoistic Suicide}

Merupakan bunuh diri yang terjadi karena adanya integrasi sosial yang terlalu lemah. Hubungan sosial yang dilakukan dalam masyarakat atau sebuah kelompok yang dimilikinya tidak begitu mengikat. Seseorang dalam kehidupan keluarga juga sangat dirasa kurang dalam komunikasi yang diembannya. Dirinya merasa sendiri karena segala bentuk pengaruh sosial yang datangnya dari luar kurang dapat menerimanya dengan baik. Segala aktivitas dilakukan tidak dapat melibatkan secara langsung kepada keluarga, teman sebaya, kelompok, atau pun masyarakat. Bunuh diri yang terjadi karena adanya tingkatan individualistik yang berlebihan. Meskipun adanya lingkungan sosial yang mendukung, tetapi jiwanya apatis. Tidak serta merta dalam sebuah keadaan sosial yang menghinggapinya. Partisipasi dalam hubungan sosial sangat kurang, dirinya lebih mementingkan rasa ego yang dibangunnya. Keterikatan yang sangat kurang dalam hal integrasi akan membuat 
seseorang menjadi alienasi. Keterasingan yang melanda dalam jangka waktu yang tidak singkat dapat menyebabkan seseorang melakukan tindakan bunuh diri. Kehidupan yang dilaluinya hanya berdasarkan pada kepentingan individu, sehingga kurang bersosialisasi dalam lingkungan sosial.

Dalam masyarakat dengan integrasi sosial yang lemah, atomistik dan individualistik setiap individu di dalamnya syarat menanggung beban hidup seorang diri, tanpa teman atau tempat untuk berbagi dan berkeluhkesah. Di Swiss, misalnya, terdapat satu jembatan yang dijaga 24 jam nonstop oleh polisi setempat akibat kerap dijadikan tempat bunuh diri para pemuda. Faktual, tingginya angka bunuh diri di negara tersebut disebabkan oleh kultur masyarakat Swiss yang mengharuskan anak muda usia 17 tahun ke atas untuk keluar rumah, mencari kerja dan hidup secara mandiri (Beautrais \& Gold, 2010: 9) (dalam Nugroho, 2012: 36).

Bunuh diri egoistik merupakan hasil dari suatu tekanan yang berlebihlebihan pada individualisme atau kurangnya ikatan sosial yang cukup dengan kelompok sosial. Jadi orang Protestan memiliki angka bunuh diri yang lebih tinggi daripada orang Katolik, karena kepercayaan mereka mendorong individualisme yang lebih besar, dan ikatan komunal dalam gereja Protestan lebih lemah (Johnson, 1986: 192). Bunuh diri egoistik terjadi manakala individuindividu yang berada di masyarakat tidak bisa berbaur dengan lingkungan setempat. Kurangnya adaptasi membuat seseorang lemah dalam solidaritas. Solidaritas sangat kurang sekali, ikatan sosial juga lemah sehingga menciptakan individu-individu yang berjalan dengan sendirinya. Tidak ada rasa kebersamaan terhadap sesama, membuat terkungkung dalam kesendirian jauh dari kolektivisme.

\section{b) Altruism Suicide}

Merupakan bunuh diri yang terjadi karena adanya integrasi sosial yang terlalu kuat. Jiwa solidaritas dari manusianya sangat tinggi, sehingga aturan-aturan yang diciptakan dalam kelompoknya akan diikuti. Menjalin hubungan sosial yang sangat kuat, keinginan-keinginan dari lingkungannya akan diwujudkan. Ikatan dalam sebuah kelompok adalah sense of belonging, jika ada anggotanya yang sakit maka sakit juga yang lainnya. Tingkat persaudaraan diatas segalanya, jalinan hubungan anatar sesama menjadi hal yang penting. Keikutsertaan dalam sebuah kegiatan menjadi hal yang prioritas. Konformitas dalam sebuah kelompok atau lingkungan sosial juga sangat tinggi. Keadaan dalam integrasi sosialyangsangatkuatdapatmenciptakan seseorang melakukan tindakan bunuh diri. Rasa yang tertorehkan sedemikian besar dalam kelompoknya, akan dilakukan untuk kepentingan apa saja. Kehidupan yang dilakukan bersumber kepada ikatan sosial yang sangat kuat sehingga integrasi dalam dirinya semakin kokoh untuk kepentingan diluar dirinya.

Disisi lain fenomena bunuh diri akibat terlampau kuatnya integrasi sosial menyiratkan pengekangan berlebih individu oleh masyarakatnya, individu serasa dikuasai penuh oleh lingkungan sosial sehingga tak dapat berbuat banyak untuk menghindarinya. Adapun fenomena bunuh diri akibat faktor terkait dibagi ke dalam beberapa tipe. Pertama, bunuh diri akibat kewajiban, dapat 
dimisalkan dengan tradisi masyarakat India kuno yang mensyaratkan istri turut mati bersama suaminya, sedang apabila sang istri menolaknya ia akan menuai cemoohan masyarakat berikut dianggap sebagai aib dalam masyarakatnya. Kedua, bunuh diri akibat dukungan masyarakat, hal tersebut dapat dicontohkan dengan seorang prajurit yang mengorbankan dirinya di medan perang demi menyelamatkan teman-temannya yang lain. Tipe bunuh diri terkait merupakan perihal yang didukung masyarakat, dalam arti siapa yang melakukannya bakal menuai penghargaan berikut penghormatan masyarakat. Ketiga, bunuh diri akibat kepuasan diri, menurut Durkheim tak ada penjelasan ilmiah bagi tindakan bunuh diri dengan tipe ini. Sang pelaku sekadar merasa bangga dan puas mempertontonkan tindakan bunuh dirinya di hadapan publik (Samuel, 2010: 60-62) (dalam Nugroho, 2012: 36-37).

Bunuh diri altruism dilakukan dengan tingkat integrasi yang terlalu kuat, manakala dirinya sudah menyatukan dengan kelompoknya. Ikatan sosial yang sangat kuat membuat jiwa solidaritasnya semakin tinggi. Ideologi yang sudah terbentuk membuat sulit lepas dari hubungan sosial yang sudah dibina. Pola pikir menjadikan keseragaman dalam kehidupannya. Apapun yang dilakukan demi keutuhan bersama dan jiwa kolektivitas diatas segalanya. Ketika segala sesuatu sudah menjadi rasa penyatuan dari dalam dirinya, maka tindakan untuk kelompok akan diembannya. Seperti fenomena bom bunuh diri yang akhir-akhir ini marak terjadi. Bom bunuh diri dilakukan dari sekelompok anggota oknum yang sudah mempunyai paham radikal. Demi kepentingan kelompok maka walaupun dirinya meninggal dunia tetap dilakukan. Ideologi dalam dirinya sudah terdoktrin untuk ikut dan mengembangkan ajaran yang dijalankannya. Bom bunuh diri sering terjadi dimana-mana, membuat masyarakat semakin resah dan panik. Tujuan yang dilakukan dari pelaku bom bunuh diri adalah mempunyai visi dan misi dari kelompoknya. Kelompok tersebut sangat bertentangan dengan ajaran nasionalisme yang ada di bangsa ini.

Bunuhdirialtruistik dapatmerupakan hasil salah satu dari dua kondisi. Pertama, norma-norma kelompok mungkin menuntut pengorbanan kehidupan individu. Sebagai contoh, bunuh diri di kalangan pilot-pilot yang bertugas dalam Angkatan Udara Jepang selama Perang Dunia II. Contoh lain dapat dilihat dalam kebiasaan-kebiasaan kuno di beberapa masyarakat dimana istri seseorang serta para pembantunya dibunuh dalam suatu upacara dan dikuburkan bersama tuannya yang sudah mati itu dengan maksud untuk memenuhi kebutuhan-kebutuhannya di dunia sana. Kedua, norma-norma kelompok itu dapat menuntut pelaksanaan tugastugas yang begitu berat untuk dapat dicapai sehingga individu-individu itu mengalami kegagalan walaupun mereka sudah menunjukkan usaha yang paling optimal.(Johnson, 1986: 193). Integrasi yang terlalu kuat dalam kelompoknya membuat individu menjadi taat kepada aturan dikelompoknya. Keikutsertaan seseorang dapat dilakukan dengan kesadaran penuh ketika ada tujuan yang ingin dicapai secara bersama. 


\section{c) Anomie Suicide}

Bunuh diri anomik muncul dari tidak adanya pengaturan bagi tujuan dan aspirasi individu. Dalam kondisi yang normal dan stabil keinginan individu dijamin oleh norma-norma yang sesuai yang didukung oleh prinsip-prinsip moral yang umum (Johnson, 1986: 192). Kekaburan norma dalam masyarakat menjadikan individu-individu bingung dan tanpa arah. Nilai dan norma yang selama ini dijadikan sebagai patokan bergeser fungsinya menjadi abu-abu. Aturan yang selama ini dijadikan pedoman dalam berperilaku dan mengambil keputusan seolah hilang begitu saja. Keinginan dan kebutuhan manusia menjadi terhambat karena keadaan yang selama ini sudah mapan tergantikan dengan keadaan yang baru. Adanya perubahan yang tidak biasa menjadi sesuatu diluar batas menyebabkan frustasi bagi masyarakat. Perubahan-perubahan yang mendadak dalam masyarakat, seperti krisis ekonomi, politik, hukum akan membawa masyarakat kearah keresahan. Fungsi yang selama ini didambakan menjadi berubah, hilangnya pegangan hidup dalam masyarakat menjadi sebuah dilematis tersendiri.

Seperti dikemukakan Durkheim, kebutuhan dan keinginan manusia tidak mungkin terpenuhi semuanya, tetapi biasanya dihambat oleh norma-norma yang sudah mapan. Kalau hambatanhambatan ini dilepaskan, keinginan manusia yang tidak habis-habisnya itu menjadi manifest. Karena meningkatnya frustasi yang muncul dari keinginan yang tidak terpenuhi itu, angka bunuh diri meningkat. Dalam menunjang proposisi ini, Durkheim menunjukkan bahwa perubahan-perubahan yang mendadak dalam masyarakat, seperti krisis ekonomi yang parah atau periodeperiode ekspansi dan kesejahteraan ekonomi yang tidak lazim, umumnya berkaitan dengan meningkatnya angka bunuh diri (Johnson, 1986: 193). Bunuh diri yang terjadi sebagai akibat dari perubahan-perubahan di masyarakat secara ekstrim. Masyarakat belum begitu siap menghadapi arus yang serba instan dan mendadak. Perubahan terjadi dengan sangat cepat, tidak semua individu dapat menerimanya dengan keadaan yang tibatiba. Norma yang selama ini dijadikan sebagai aturan, hilang tanpa arah.

Bunuh diri anomik mencerminkan seorang individu yang mengalami kebingungan moral dan kurangnya arah sosial yang berkaitan dengan pergolakan sosial dan ekonomi yang dramatis. Seorang individu tidak tahu dibidang mana mereka cocok dalam komunitas mereka (Mantiri, Erwin dan James, 2016: 260). Keadaan yang membuat bingung masyarakat menjadikan suasana masyarakat tidak harmonis. Terlebih terjadinya perubahan yang tidak semuanya masyarakat dapat menerimanya dengan baik. Menurut Upe (2010: 102), keadaan anomi ini dapat melanda seluruh masyarakat ketika terjadi perubahan sosial, politik, hukum, dan budaya pada masyarakat secara revolusioner. Kendati demikian, dilain pihak masyarakat belum sepenuhnya menerima perubahan karena nilai-nilai lama pada masyarakat belum begitu dipahami, sementara nilai-nilai yang baru belum jelas. 


\section{d) Fatalistic Suicide}

Tipebunuh diriyang demikianinitidak begitu banyak dibahas oleh Durkheim. Pada tipe bunuh diri anomi terjadi dalam situasi dimana nilai dan norma yang berlaku di masyarakat melemah. Lain halnya pada bunuh diri diri fatalistik, ini terjadi ketika nilai dan norma yang berlaku di masyarakat meningkat dan terasa berlebihan (Upe, 2010:103). Fatalistic suicide merupakan bunuh diri yang terjadi karena adanya aturan-aturan yang berada di masyarakat meningkat. Aturan yang terlalu kuat sangat membatasi terhadap gerak masyarakat. Individu yang tidak siap menjadi tertekan oleh tatanan nilai dan norma dalam masyarakat. Nilai dan norma yang sudah menindas menjadikan masyarakat hanya taat dan patuh terhadap sebuah kebijakan. Individu-individu yang berada di masyarakat tidak bisa berbuat apa-apa, hanya pasrah pada keadaan nasib. Jiwa fatalis sudah membelenggu dalam kehidupannya. Pengekangan dalam sebuah norma tetap dijalankan dengan dalih hanya menjalankan sebuah peraturan. Norma yang terlampau kuat ini membuat ketidakberdayaan pada individu-individu di masyarakat. Segala sesuatu yang dijalankan berhubungan erat dengan aturan. Manakala jiwa individu sudah mengalami titik puncak dalam keengganannya mengikuti nilai dan norma maka bunuh diri menjadi jalan pintas yang harus dilakukan. Durkheim (dalam Upe 2010: 103), menggambarkan seseorang yang melakukan bunuh diri fatalistik seperti seseorang yang masa depannya telah tertutup dan nafsu yang tertahan oleh nilai dan norma yang menindas, sebagai contoh pada masyarakat budak.
Bunuh diri fatalistik terjadi ketika seseorang terlalu diatur atau terkekang, ketika masa depan mereka diblokir tanpa belas kasihan dan keinginan diri-sendiri dihambatkarena disiplin yang berlebihan. Ini adalah kebalikan dari bunuh diri anomik dan muncul dalam masyarakat terlalu menindas menyebabkan individu lebih memilih mati daripada melanjutkan hidup dalam masyarakat mereka (Mantiri, Erwin dan James, 2016: 260). Norma yang terlalu kuat akan membuat seseorang menjadi takhluk. Ketika aturan sudah dijalankan, masyarakat harus tunduk dan patuh untuk mengikutinya. Sekelompok orang yang mendekam di penjara maka kebebasan untuk hidup dan bermasyarakat sudah hilang, terlebih mendapat hukuman yang lama di dalam sel tahanan. Tidak jarang ditemukan juga beberapa orang mengakhiri hidupnya dengan jalan melakukan bunuh diri karena adanya tekanan yang berlebih selama berada dalam kehidupan penjara.

Berdasarkan tipe bunuh diri yang ada maka terdapat empat jenis bunuh diri dalam pandangan Emile Durkheim. Secara ringkas dapat dikelompokkan menurut tabel yang ada di bawah ini:

\begin{tabular}{|c|c|c|}
\hline No & $\begin{array}{c}\text { Tipe Bunuh } \\
\text { Diri }\end{array}$ & $\begin{array}{r}\text { Nilai \& } \\
\text { Norma } \\
\text { Sosial }\end{array}$ \\
\hline 1 & Egoistic suicide & Integrasi sosial (-) \\
\hline 2 & Altruism suicide & Integrasi sosial $(+)$ \\
\hline 3 & Anomie suicide & Nilai, Norma (-) \\
\hline 4 & Fatalistic suicide & Nilai, Norma (+) \\
\hline
\end{tabular}

Tabel 1 Tipe Bunuh Diri dan Integrasi Sosial 
Dari gambar tabel tersebut dapat dijelaskan bahwa tindakan bunuh diri berdasarkan empat tipe bunuh diri yaitu: egoistic suicide, altruism suicide, anomie suicide, dan fatalistic suicide. Tipe bunuh diri yang dilakukan mempunyai ciri pembeda dalam tingkatan bunuh diri. Egoistic suicide lebih menekankan karena adanya integrasi sosial yang sangat kurang. Altruism suicide lebih mengarah pada tindakan bunuh diri karena adanya integrasi sosial yang terlampau sangat kuat. Sementara Anomie suicide disebabkan karena terbentuknya nilai dan norma yang sangat melemah atau kekaburan dalam hal nilai dan norma dalam masyarakat. Sedangkan Fatalistic suicide yang menyebabkan seseorang melakukan tindakan bunuh diri karena dilatarbelakangi oleh nilai dan norma yang sangat mengekang di dalam masyarakat.

Sebenarnya dalam tindakan bunuh diri yaitu antara integrasi sosial dan nilai, norma mempunyai hubungan yang sangat erat. Integrasi dalam seseorang lemah maka besar kemungkinan tidak dapat mengikuti nilai dan norma dalam kelompoknya atau masyarakat. Sebaliknya, integrasi yang kuat maka nilai dan norma yang dilakukan juga semakin berjalan kearah dalam konformitas di sebuah kelompoknya. Adapun ketika nilai dan norma melemah, maka keinginan untuk taat pada aturan juga berkurang atau tidak menunjukkan besarnya harapan dalam tata aturan tersebut. Sementara nilai dan norma yang menguat sekali maka integrasi juga tidak terbantahkan, menjadikan seseorang akan ikut dalam suatu kelompoknya. Tentunya ikatan seseorang dalam kelompoknya didasarkan pada keadaan menerima dalam kelompoknya atau malah berkebalikan yaitu menolak dalam ketidakinginannya. Nilai dan norma juga membuat seseorang menjadi tunduk dan patuh dalam aturan yang ada, sementara jiwa pemberontak terhadap aturan juga tidak terelakkan.

\section{PENUTUP}

\section{Kesimpulan}

Bunuh diri merupakan sebuah fakta sosial dimana keadaan tersebut terdapat di berbagai lapisan masyarakat. Gejalagejala yang nampak berada pada gejala sosial bukan gejala individu. Pengaruh dari hubungan sosial dan struktur sosial dalam masyarakat sangat mempengaruhi terhadap perilaku individu-individu. Berkaitan dengan bunuh diri yang terjadi dalam lingkungan sosial atau masyarakat dapat dianalisis dengan empat macam tipe bunuh diri, yaitu: Egoistic suicide, Altruism suicide, Anomie suicide, dan Fatalistic suicide. Tipe bunuh diri tersebut sangat berhubungan dengan keadaan masyarakat. Integrasi sosial yang dimiliki oleh individu sangat menentukan terhadap tindakan bunuh diri. Apabila integrasi sosial sangat kuat maka akan memungkinkan seseorang melakukan tindakan altruism suicide, sedangkan integrasi sosial yang sangat lemah, maka seorang individu akan menempuh jalan egoistic suicide. Sementara dalam tatanan sosial tidak selamanya berjalan sesuai dengan kemapanan sosial. Nilai dan norma yang kabur menjadikan masyarakat semakin bingung dan kacau. Tidak adanya pegangan nilai dan norma yang dijadikan patokan dalam bertindak. Individu merasa kehilangan cita-cita, tujuan, dan norma dalam hidupnya, sehingga melakukan anomie 
suicide. Sedangkan jika nilai dan norma dalam masyarakat meningkat dan sangat berlebihan, maka yang terjadi hanyalah patuh dan taat pada keadaan. Pasrah pada nasib menjadi jalan yang harus dilaluinya. Apabila tekanan yang dilaluinya semakin hari semakin tidak dapat dibendung, maka jalan yang ditempuh adalah fatalistic suicide. Penindasan dari sebuah tata aturan yang semakin merajalela. Ketidakberdayaan masyarakat semakin lemah dan tak berdayakan lagi dalam sendi-sendi kehidupan.

\section{DAFTAR PUSTAKA}

Edi, Fandi. R. S. dan Biroli, Alfan. 2017. Psikologi Sosial. Malang: AE Publishing.

Gamayanti, Witrin. 2014. Usaha Bunuh Diri Berdasarkan Teori Ekologi Bronfenbrenner. Jurnal Psympathic, Vol. 1, No. 2.

Johnson, Doyle Paul. 1986. Teori Sosiologi Klasik dan Modern. Jakarta: Gramedia.

Mantiri, Arthur. D.B., Erwin. G.K, dan James.S. 2016. Profil Kasus Bunuh
Diri di Kota Manado Periode JanuariNovember 2015. Jurnal e-Clinic, Vol. 4, No. 1.

Nugroho, Wahyu Budi. 2012. Pemuda, Bunuh Diri dan Resiliensi: Penguatan Resiliensi sebagai Pereduksi Angka Bunuh Diri di Kalangan Pemuda Indonesia. Jurnal Studi Pemuda, Vol. 1, No. 1.

Ritzer, George. 2011. Sosiologi Ilmu Pengetahuan Berparadigma Ganda. Jakarta: RajaGrafindo Persada.

Sunarto, Kamanto. 2004. Pengantar Sosiologi. Jakarta: FE Universitas Indonesia.

Upe, Ambo. 2010. Tradisi Aliran dalam Sosiologi. Jakarta: RajaGrafindo Persada.

Usman, Sunyoto. 2012. Sosiologi: Sejarah, Teori, dan Metodologi. Yogyakarta: Pustaka Pelajar.

Valentina, Tience Debora dan Helmi, Avin Fadilla. 2016. Ketidakberdayaan dan Perilaku Bunuh Diri: Meta-analisis. Buletin Psikologi, Vol. 24, No. 2.

Widodo, T. 2011. Sosiologi Kependudukan. Surakarta: LPP UNS dan UNS Press. 